\title{
Correlation between NK function and response to trastuzumab in metastatic breast cancer patients
}

\author{
Alessandra Beano1, Elena Signorino ${ }^{2}$, Andrea Evangelista ${ }^{3}$, Davide Brusa ${ }^{2}$, \\ Marinella Mistrangelo ${ }^{1}$, Maria Antonia Polimeni ${ }^{1}$, Rosella Spadi ${ }^{1}$, \\ Michela Donadio ${ }^{1}$, Libero Ciuffreda ${ }^{1}$ and Lina Matera*2
}

\begin{abstract}
Address: ${ }^{1}$ Dept of Medical Oncology, Molinette's Hospital, Turin, Italy, ${ }^{2}$ Laboratory of Tumour Immunology, Dept of Internal Medicine, University of Turin, Italy and ${ }^{3}$ Unit of Cancer Epidemiology, S. Giovanni Battista, Hospital and CPO Piemonte, Turin, Italy

Email: Alessandra Beano - gv.beano@accademiaservice.it; Elena Signorino - elena.signorino@unito.it;

Andrea Evangelista - andrea.evangelista@cpo.it; Davide Brusa - davide.brusa@unito.it; Marinella Mistrangelo - mmistra@yahoo.it; Maria Antonia Polimeni - ma.polimeni@tiscali.it; Rosella Spadi - mspadi@yahoo.it; Michela Donadio - arly.donadio@alice.it;

Libero Ciuffreda - lciuffreda@molinette.piemonte.it; Lina Matera* - lina.matera@unito.it

* Corresponding author
\end{abstract}

Published: 16 May 2008

Journal of Translational Medicine 2008, 6:25 doi:10.1 I86/1479-5876-6-25
Received: 14 March 2008

Accepted: 16 May 2008

This article is available from: http://www.translational-medicine.com/content/6/I/25

(C) 2008 Beano et al; licensee BioMed Central Ltd.

This is an Open Access article distributed under the terms of the Creative Commons Attribution License (http://creativecommons.org/licenses/by/2.0), which permits unrestricted use, distribution, and reproduction in any medium, provided the original work is properly cited.

\begin{abstract}
Background: Trastuzumab is a monoclonal antibody selectively directed against Her2 and approved for the treatment of Her2 overexpressing breast cancer patients. Its proposed mechanisms of action include mediation of antibody-dependent cellular cytotoxicity (ADCC) by triggering Fc $\gamma$ RIII on natural killer (NK) cells. This study addresses the correlation between overall NK function and trastuzumab's clinical activity.
\end{abstract}

Subjects and methods: Clinical and immunological responses were assessed in 26 patients receiving trastuzumab monotherapy as maintenance management after chemotherapy $(8 \mathrm{mg} / \mathrm{kg}$ load and then standard doses of $6 \mathrm{mg} / \mathrm{kg}$ every 3 weeks). Cytotoxic activity against the MHC class I-negative standard NK target K562 cell line and HER2-specific ADCC against a trastuzumabcoated Her2-positive SKBR3 cell line were assessed in peripheral blood mononuclear cells (PBMC) harvested after the first standard dose. After six months, seventeen patients were scored as responders and nine as non-responders according to the RECIST criteria, while Progression-Free Survival (PFS) was calculated during a 12 months follow-up.

Results: The responders had significantly higher levels of both NK and ADCC activities $(p<0.05)$ that were not different from those of eleven normal controls. The NK activity of the nonresponders was significantly $(p<0.05)$ lower than that of the normal controls. At twelve months, there was a marked correlation between PFS and NK activity only. PFS was significantly longer in patients with high levels of NK activity, whereas its pattern was unrelated to high or low ADCC activity.

Conclusion: One of the mechanisms of action of trastuzumab is NK cell-mediated ADCC lysis of the Her2-positve target cell. We show here that its potency is correlated with the short-term response to treatment, whereas longer protection against tumor expansion seems to be mediated by pure NK activity. 


\section{Background}

Breast cancer is the second most common cancer in the world (after lung cancer), and a major cause of cancerrelated death in women [1].

Human Epidermal Growth Factor Receptor 2 (Her2), a member of the ErbB family that plays an important role in promoting oncogenic transformation and tumour growth [2] is overexpressed in $20-30 \%$ of patients $[3,4]$. This overexpression correlates with poor prognosis, including high risk of recurrence, metastases and reduced overall survival $[2,5,6]$.

Trastuzumab is a humanised monoclonal antibody that selectively targets Her2. Its use is approved for the treatment of women with Her2-overexpressing breast cancer, as determined by an accurate and validated assay [7-9]. Enhancement of Her2 degradation, inhibition of cell cycle progression via inhibition of the mitogen-activated protein kinase pathway and suppression of antiapoptotic phosphatylinositol 3-kinase and Akt pathways have been shown to follow its binding to Her2-overexpressing cells [10-15]. However, only 25-30\% [10] or $18 \%$ [15] of patients with Her2 over-expression respond to treatment. There is thus a need to find predictive response markers in order to select patients likely to benefit from this treatment and spare others its adverse effects [15]. Reliable markers may emerge from evaluation of all the players involved in trastuzumab-mediated tumor regression.

Both cytostatic and cytolytic mechanisms account for the clinical effect of trastuzumab. Her2-related cytotoxicity includes complement-mediated and antibody-dependent cellular cytotoxicity (ADCC) mediated by FcyRIII [16-22]. Cell subsets that mediate ADCC include neutrophils, monocytes, and natural killer (NK) cells. NK cells are cytotoxic in two ways. First, they spontaneously lyse virusinfected or transformed cells in the absence of prior sensitization. Since this activity is under the dominant control of inhibitory receptors (iNKRs) that bind class I human leukocyte antigen (HLA), it is thought to be only effective against tumor cells that lack MHC class I or present a dominant-activating ligand. Second, NK cells recognize and kill antibody-coated target cells during ADCC [1923]. Increased number of NK cells at the tumor site after trastuzumab and a correlation between NK tumor infiltration and clinical response [22] are convincing evidence of their participation in tumor clearance. The present study addresses the significance of NK cells in the mechanism of action of trastuzumab by comparing their functional state and the clinical outcome in metastatic breast cancer patients.

\section{Methods \\ Patients}

Twenty-six metastatic breast cancer patients (Table 1) received trastuzumab as a single agent after chemotherapy in the form of an $8 \mathrm{mg} / \mathrm{kg}$ load followed by $6 \mathrm{mg} / \mathrm{kg}$ standard doses every 3 weeks for 1 year, or until evidence of disease progression or unacceptable toxicity. NK and ADCC activities were assessed in occasion of the first standard dose. Clinical response was evaluated radiologically and classified according to the RECIST criteria. Patients experiencing CR, PR and SD were considered responders, as opposed to PD patients who were considered non-responders (Table 1).

\section{Cytokines and Antibodies}

Recombinant human IL-2 was purchased from Chiron (Milan, Italy). The humanized anti-Her2 MoAb trastuzumab was kindly provided by Genentech Inc. (San Francisco, California, USA).

Table I: Characteristics of patients

\begin{tabular}{lccc}
\hline Patient \# & Type of mts & No. of $m$ ts & Response \\
\hline 999 & Visceral & $>3$ & DP \\
1025 & Visceral & $<3$ & CR \\
1080 & Visceral & $>3$ & DP \\
1081 & Visceral & $<3$ & DP \\
1083 & Visceral & $>3$ & PR \\
1095 & Visceral & $<3$ & CR \\
1125 & Visceral & $>3$ & DP \\
1126 & Visceral & $<3$ & SD \\
1102 & Non-visceral & $>3$ & CR \\
1103 & Non-visceral & $<3$ & SD \\
1110 & Non-visceral & $<3$ & CR \\
1121 & Non-visceral & $>3$ & DP \\
1123 & Non-visceral & $<3$ & SD \\
1124 & Non-visceral & $<3$ & CR \\
1019 & Mixed & $>3$ & PR \\
1020 & Mixed & $>3$ & SD \\
1021 & Mixed & $>3$ & PR \\
1026 & Mixed & $>3$ & DP \\
1082 & Mixed & $>3$ & DP \\
1104 & Mixed & $>3$ & PR \\
1105 & Mixed & $>3$ & SD \\
1116 & Mixed & $>3$ & DP \\
1270 & Visceral & $<3$ & RC \\
1276 & Mixed & $>3$ & PR \\
1279 & Non-visceral & $<3$ & PR \\
1280 & Visceral & $>3$ & PD \\
& & & \\
\hline & & &
\end{tabular}

IVisceral mts: liver, lungs, CNS

${ }^{2}$ Non-visceral metastases (mts): bones, locoregional lymph nodes, skin

3Mixed: visceral and non-visceral

DP: disease progression; CR: complete remission; PR: partial remission; SD: stable disease. 


\section{Cell lines}

The human breast adenocarcinoma lines SKBR3 and MCF7 were grown as adherent cells and used as Her2-positive and Her2-negative lines, respectively. The non-adherent leukaemia cell line K562 [24] was used as an MHC class I-negative, NK susceptible target. Its NK susceptibility was tested in pilot and concurrent experiments against the standard NK-resistant DAUDI cell line. Culture medium was RPMI 1640 (Life Technologies Ltd, Paisley, Scotland, UK) supplemented with 20\% (SKBR3 and MCF7) or 10\% (K562) heat inactivated fetal calf serum (FCS), 1\% L-glutamine, 1\% penicillin and streptomycin (Sigma-Aldrich, Milan, Italy).

\section{Isolation of PBMC}

Peripheral blood mononuclear cells (PBMC) obtained after Ficoll-Hypaque density centrifugation of venous blood of patients and age-matched normal donors were washed in RPMI 1640 supplemented with 5 mM EDTA (Sigma-Aldrich) and 2\% heat inactivated FCS and resuspended in RPMI 10\% FCS.

\section{ADCC and NK cytotoxicities}

To evaluate ADCC, the SKBR3 and MCF7 breast cancer cell lines were incubated with $10 \mu \mathrm{g} / \mathrm{ml}$ trastuzumab at $4{ }^{\circ} \mathrm{C}$ for 30 minutes. The mAb excess was removed by washing at $4^{\circ} \mathrm{C}$ to prevent capping and $\mathrm{Ag}$-Ab complexes endocytosis. The cells were used as targets in a ${ }^{51} \mathrm{Cr}$ release cytotoxicity assay, where the mAb uncoated K562 line was used to evaluate NK activity. This assay was conducted as previously described [25]. Briefly, targets cells were incubated with $100 \mu \mathrm{Ci} \mathrm{Na}_{2}{ }^{51} \mathrm{CrO}_{4}$ (Perkin Elmer, Milan, Italy), for $1 \mathrm{~h}$, washed and added ( $5 \times 10^{3} /$ well of a 96well V-bottomed plate) to different numbers of effector cells to obtain decreasing effector to target (E:T) ratios (50:1, 25:1 and 12:1), or cultured with medium alone or TritonX-100. Plates were incubated at $37^{\circ} \mathrm{C}$ for $4 \mathrm{~h}$, and the supernatant $(100 \mu \mathrm{l})$ was harvested for quantification in a $\gamma$-counter. Triplicate wells were set up for each E:T dilution and the percentage of lysis was calculated according to the formula: (experimental release - spontaneous release $) /($ maximal release - spontaneous release $) \times 100$, where experimental release represents the mean counts per minute (cpm) for the target cells in the presence of effector cells, spontaneous release represents the mean cpm for target cells incubated without effector cells, and maximal release represents the mean cpm for target cells incubated with TritonX-100. Experiments with spontaneous releases higher than $10 \%$ (for the non-adherent cell line K562) or 20\% (for the adherent cell lines SKBR3 and MCF7) were not considered.

\section{Statistics}

Responder and non-responder groups were compared using unpaired Student's t-test and Welch's t-test for une- qual variance. Receiver operating characteristic (ROC) curve analysis was performed to detect optimal cut-off points of NK and ADCC to evaluate the clinical response at six months. For Progression-Free Survival (PFS) analysis, Kaplan-Meier curves were produced and compared with Log-Rank tests. The statistical package STATA 9.2 was used for all statistical tests and a two-tailed p-value of less than .05 was considered significant.

\section{Results \\ Expression of Her2 on SKBR3 and MCF7 cell lines}

Since conflicting assessment have been made of the expression of Her2 on MCF7 cells $[17,19,22]$, we have unequivocally stated the Her2 expression of our two lines. Results show that the SKBR3 is highly Her2-positive, whereas the MCF7 line is substantially Her2-negative (Fig. 1).

\section{In vitro cytotoxicity of NK targets and breast tumor targets by patient's PBMC correlates with their clinical response at six months}

Patients undergoing trastuzumab monotherapy after trastuzumab-chemotherapy association were tested for NK activity against the NK target K562 and for ADCC activity against the trastuzumab-coated Her2-positive cell line SKBR3 in a ${ }^{51} \mathrm{Cr}$ release assay. The Her2-negative cell line MCF7 was employed as a negative control for the ADCC. After six months seventeen patients were classified as responders (CR, PR and SD) and nine as non-responders (PD) according to the RECIST criteria (Table 1). Both NK (Fig. 2A). and ADCC (Fig. 2B). activities were two-fold higher in the responders. This difference was significant at all three E:T ratios. As expected, ADCC against the Her2negative cell line MCF7 was much lower than that against the SKBR3 cell line (Fig. 2C). Furthermore, the NK and ADCC activities of responders were not different from those of eleven normal controls (Fig 3A and 3B), whereas the NK activity of the non-responders was significantly lower (Fig. 4A) and their ADCC activity (Fig. 4B) was clearly lower than normal, though only significant at the highest E:T ratio.

\section{Correlation between NK and ADCC activities and PFS}

The Kaplan-Meier PFS curve showed that 25\% and 50\% of patients were in PD at 6 and 12 months respectively (Fig. 5). ROC analysis was used to provide an optimal cut-off for discrimination of high an low NK and ADCC activities at the three E:T ratios and stratified PFS curves were created. Results show that patients with higher levels of NK activity are significantly less likely to relapse within twelve months (Log-Rank test p-values 0.168, 0.033 an 0.024 at the 50:1, 25:1 and 12:1 E:T ratios respectively (Fig. 6). By contrast, the advantage of a high ADCC activity is only evident at six months. At twelve months, the percentage of 

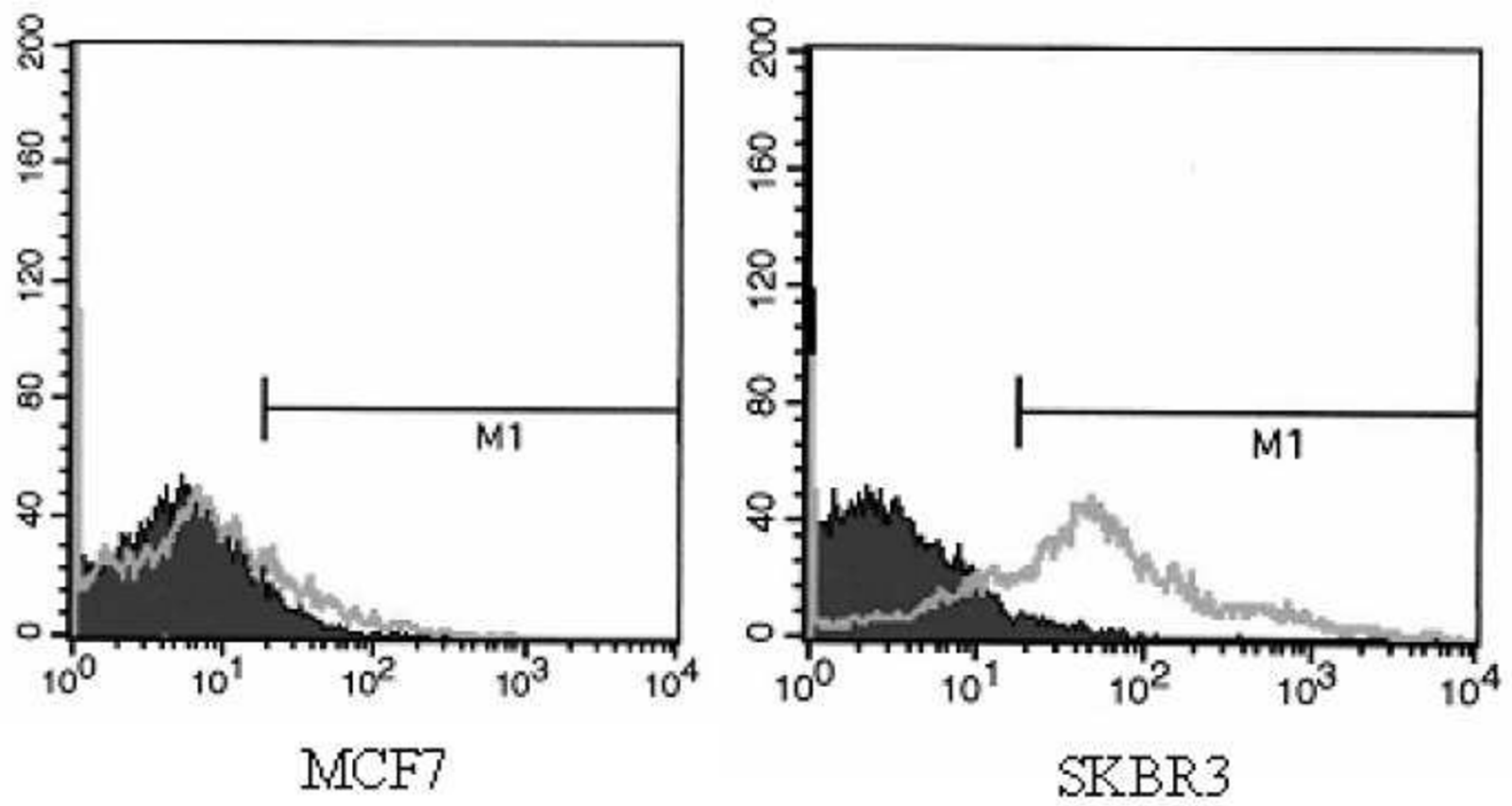

Figure I

Different Her2 expression of the ADCC target cell lines. The human breast carcinoma cell lines MCF7 and SKBR3 were stained with the humanized anti-Her2 MoAb trastuzumab (Genentech Inc. San Francisco, California, USA) and analysed by flow cytometry.

relapsing patients with either a high or a low initial ADCC activity is $50 \%$ (Fig. 7 ).

\section{Discussion}

Patients with Her2-overexpressing breast tumors normally become resistant to trastuzumab after one year. Hence, in addition to protein overexpression and gene amplification of Her2, other predictive response markers are needed to optimize its clinical use.

Since NK cell-mediated killing of the mAb-coated Her2positive autologous tumor is part of the mechanism of action of trastuzumab, the functional state of NK cells may also critically influence the clinical outcome. We have therefore correlated this pretreatment biomarker with clinical response to trastuzumab after 6 months and 12 months. Results show that the short-term response rests on efficient NK and ADCC functions, whereas the long-term response is correlated with high NK function, but is independent of the ADCC profile.

In vitro studies $[17,19]$ have demonstrated that NK cells kill trastuzumab-coated Her2-overexpressing cells via a Fc $\gamma$ RIII receptor-mediated ADCC mechanism. This activity is very likely to recapitulate the destiny of the host tumor cells upon trastuzumab administration. Indeed, the significance of antibody-mediated killing in the clinical effect of humanized mAbs has been confirmed by clinical data [26]. In particular, experimental [17,19] and clinical $[21,22]$ data point to the importance of the Fc $\gamma \mathrm{R}$ in trastuzumab's clinical efficiency PBMC from trastuzumab-treated patients displayed cytopathic activity in vitro against Her2-overexpressing cells. ADCC activity was more pronounced in tumours demonstrating a good response [21]. Moreover, increased infiltration of NK cells has been observed at the tumor site after trastuzumab [22]. However, evaluation of ADCC in metastatic breast cancer patients treated with a combination of trastuzumab and interleukin-2 (IL-2) [20,26] or IL-12 [27] (two activators of NK cells) did not confirm a correlation with clinical responses.

Our data show that patients with normal levels of both NK and ADCC activities respond more favourably to trastuzumab after a six month observation.

The ADCC performance status seems to depend on individual-related characteristics [28] such as Fc $\gamma \mathrm{R}$ polymorfisms $[28,29]$, as well as the relative frequency of Fc $\gamma R$ (CD16+)CD3+ vs CD56+CD3- NK subpopulations [[29] and our unpublished data], rather than on the individual trastuzumab pharmacokinetics [29]. 

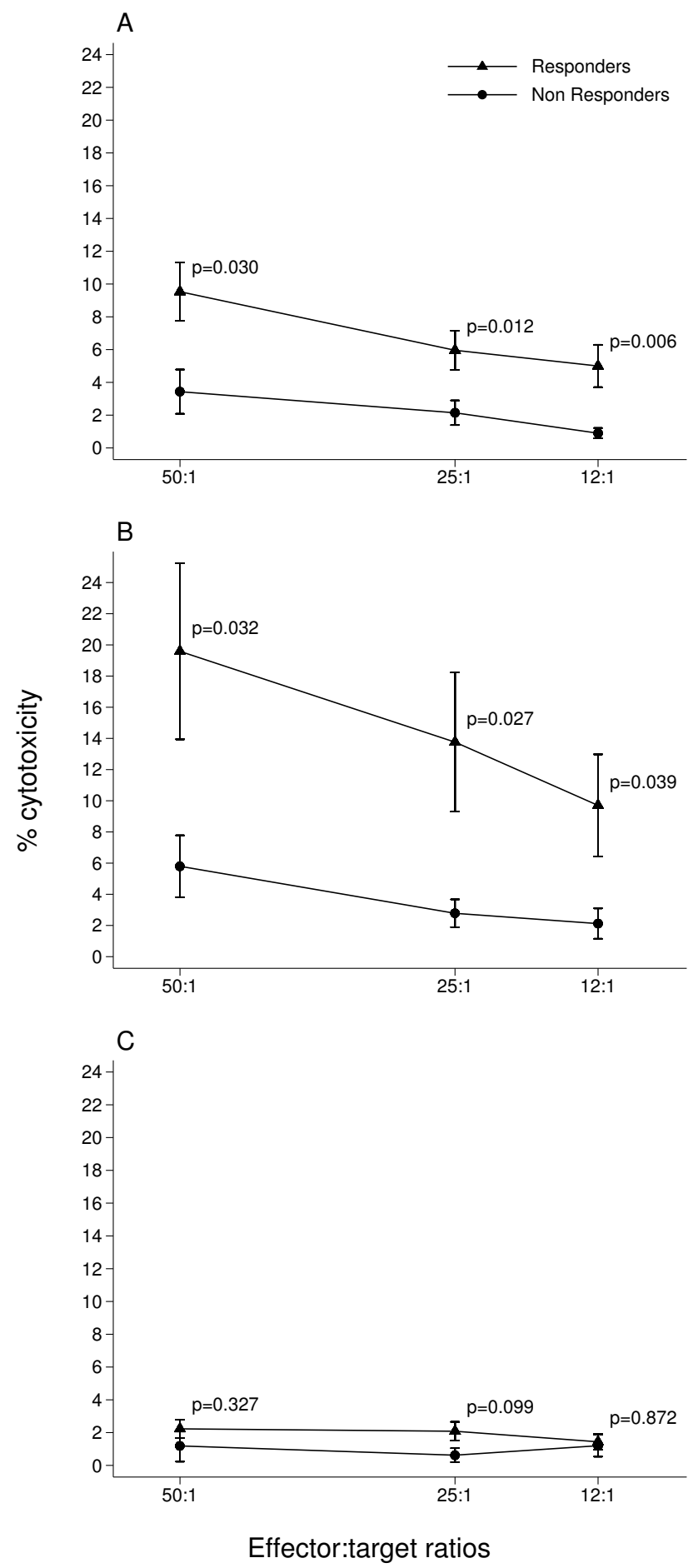

Figure 2

NK and ADCC profile of patients classified as responders and non-responders after a six-month trastuzumab regimen. NK and ADCC activities of PBMC were tested at the start of trastuzumab therapy against the target $\mathrm{K} 562$ cell line (A) and the trastuzumab-coated Her2-positive cell line SKBR3 (B) in a ${ }^{51} \mathrm{Cr}$ release assay. The trastuzumab-coated Her2-negative cell line MCF7 (C) was used as control for ADCC. Values of NK (A) and ADCC (B) cytotoxicity were always significantly higher in responders at all three $\mathrm{E}: \mathrm{T}$ ratios. 

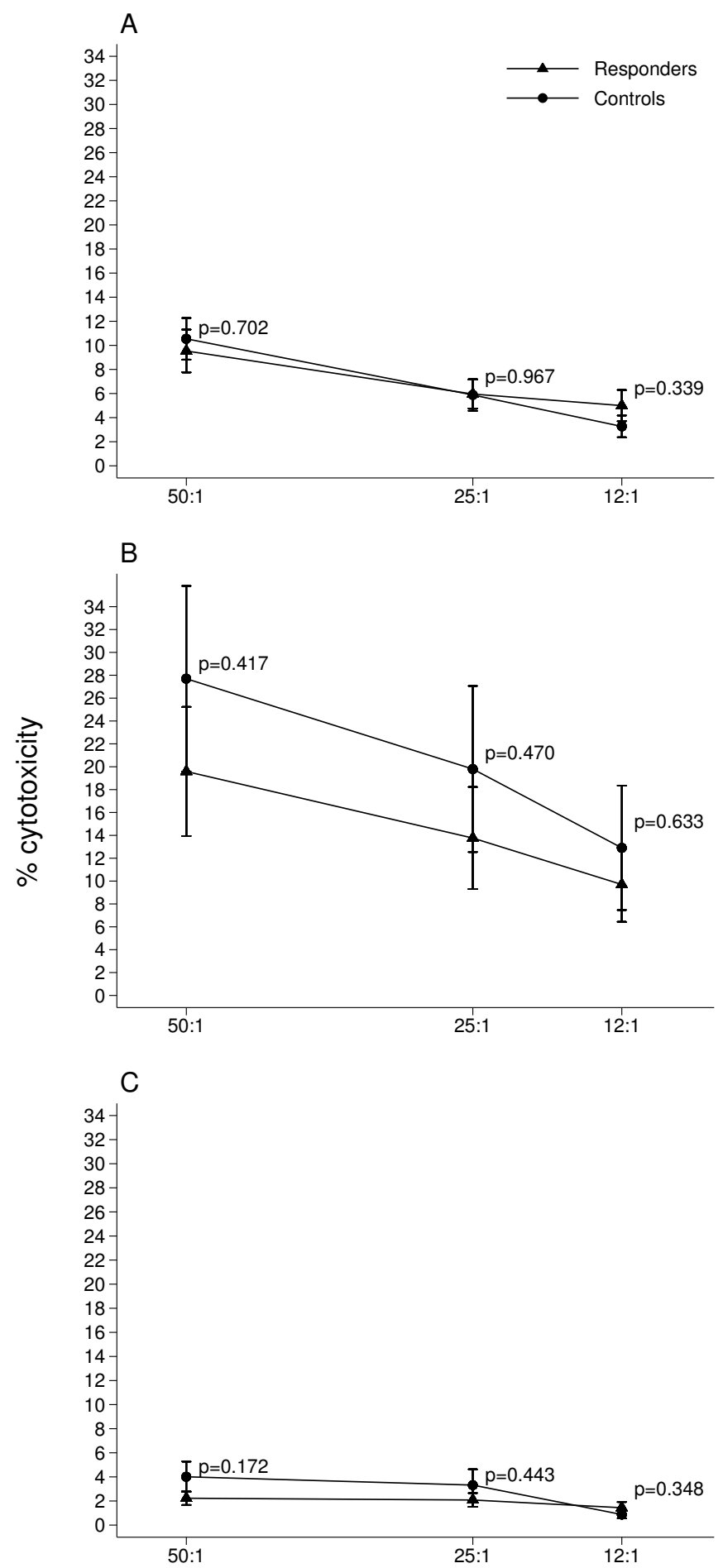

Effector:target ratios

\section{Figure 3}

Responders have normal NK and ADCC activities. NK and ADCC activities were assessed as described in legend to Fig. 2. Values (A and $B$ ) were not significantly different in responders compared to II normal donors at all three $E$ : $T$ ratios. As expected, negligible ADCC activity was found both in patients and normal donors against the Her2-negative cell line MCF7 (C). 

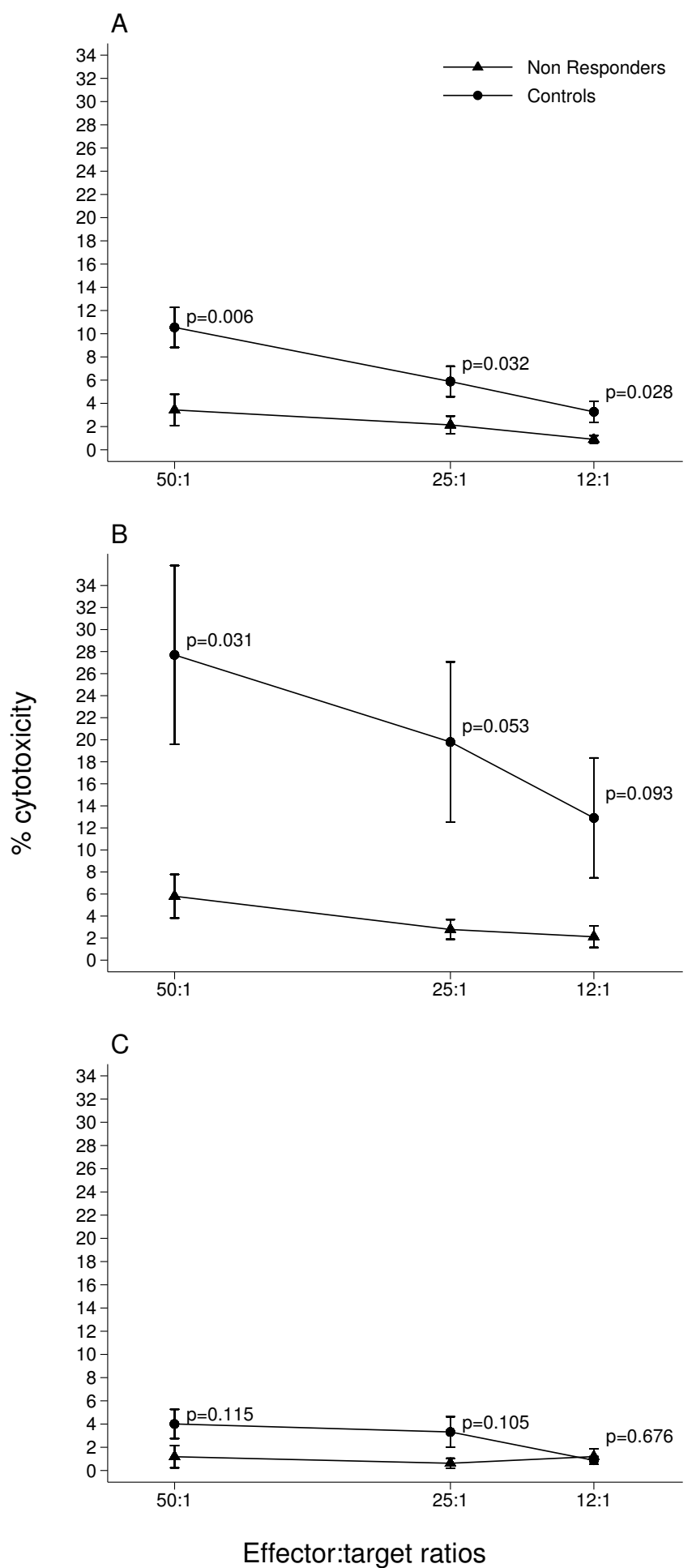

\section{Figure 4}

Non-responder patients have defective NK activity. NK and ADCC activities were assessed as described in legend to Fig. 2. Values of NK activity $(A)$ were significantly lower in patients compared to normal donors at three $E: T$ ratios. ADCC activity (B) was significantly lower in patients only at the highest E:T ratio. As expected, negligible ADCC activity was found both in patients and normal donors against the Her2-negative cell line MCF7 (C). 


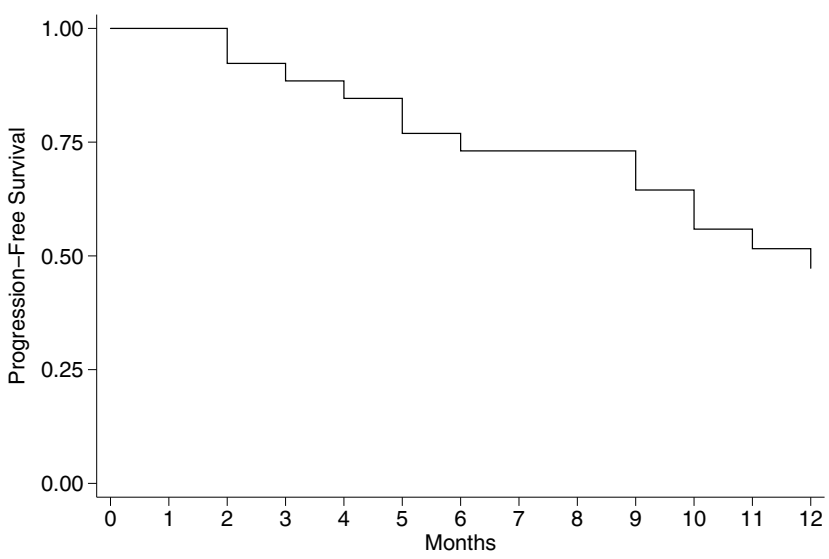

Figure 5

Global time to tumor progression at twelve months. The Kaplan-Meier PFS curve shows that the percentage of progression-free patients is $75 \%$ at six months from start of Trastuzumab therapy and declines to $50 \%$ at twelve months.

Whatever the mechanisms that determine an effective ADCC response in trastuzumab- responsive patients, this was confined in our study to the early observation period.

Longer evaluation of the response to trastuzumab, in terms of progression-free survival after twelve months showed a strong correlation with the levels of NK activity only. By this time $75 \%$ of patients with low NK activity had relapsed, whereas the same percentage of those with high NK activity were still progression-free. By contrast,
$50 \%$ of patients who had progressed after twelve months could not been distinguished through their ability to perform ADCC in vitro. This suggests that NK cells can protect against breast cancer progression in an antibodyindependent fashion, a likely mechanism being targeting of immunoedited MHC class I defective tumor cells [30].

Taken as a whole, our data show that the efficiency of the NK system may be a hallmark of responsiveness to trastuzumab and suggest that breast cancer patients eligible for its administration may benefit from enhancement of this system in vivo. This includes combination therapy with trastuzumab and immunomodulatory agents or construction of bispecific antibodies targeting HER2 and CD16 [31] The first approach seems the more feasible. The fact that in vivo NK cell expansion and increased in vitro ADCC by IL-2 [20] or IL-12 [26,27] did not result in evident clinical benefits may merely mean that optimal combination of NK stimulators has still be found. A NK stimulation threshold, represented by a combination of IL-2 and IL-12 activates both the ADCC function and release of the antitumor cytokines and chemokines and is prone to be applied to clinical models [32]. IL-21 is also a promising NK stimulator, since it enhanced the effects of cetuximab in a murine tumor model and the human NK cell response to Ab-coated targets [33]. Once the mechanisms of ADCC function and the populations involved are characterized adoptive transfer of ex-vivo expanded purified ADCC effectors could be envisaged.
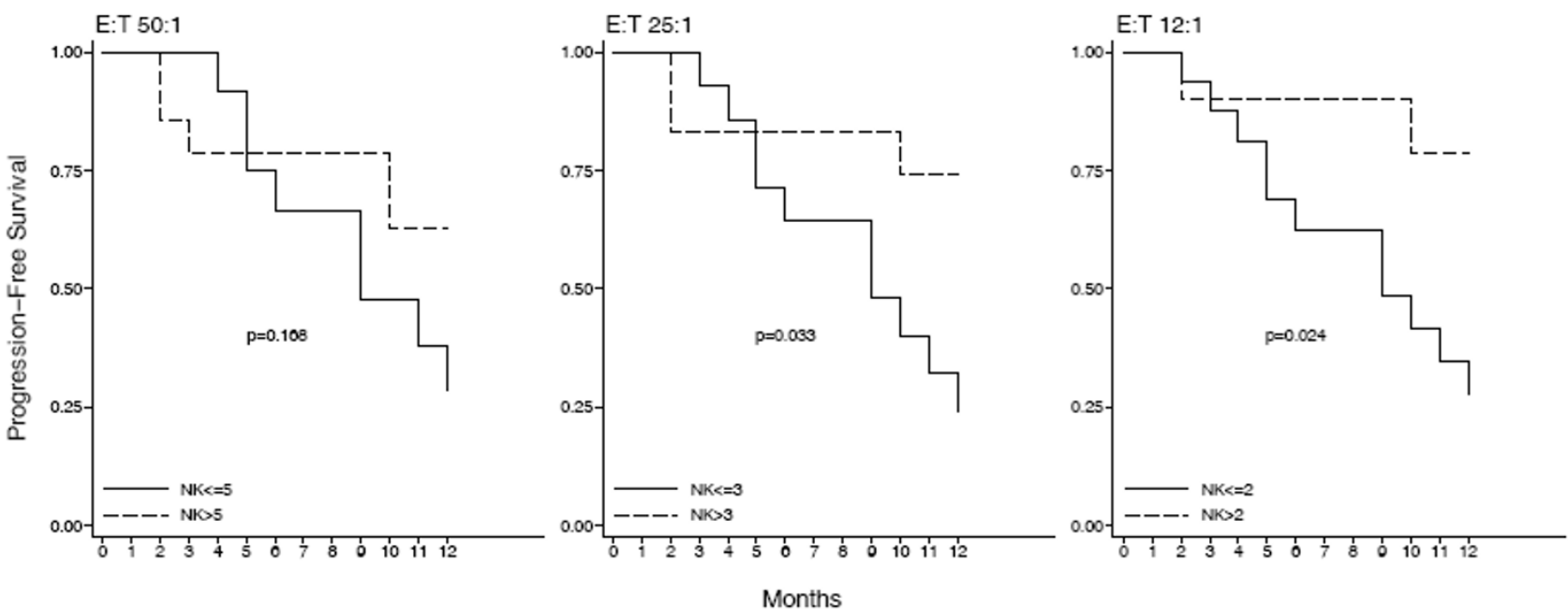

\section{Figure 6}

Time to tumor progression is correlated with the NK activity. A cut-off of $5 \% .3 \%$ and $2 \%$ cytotoxicity was chosen to discriminate between high and low NK levels at the three E:T ratios of 50:I, 25:I and I2:I respectively and a stratified PFS curve was created from these values. The figure shows that higher NK values are significantly (Log-Rank test $P$ values) correlated with longer time to tumor progression. 

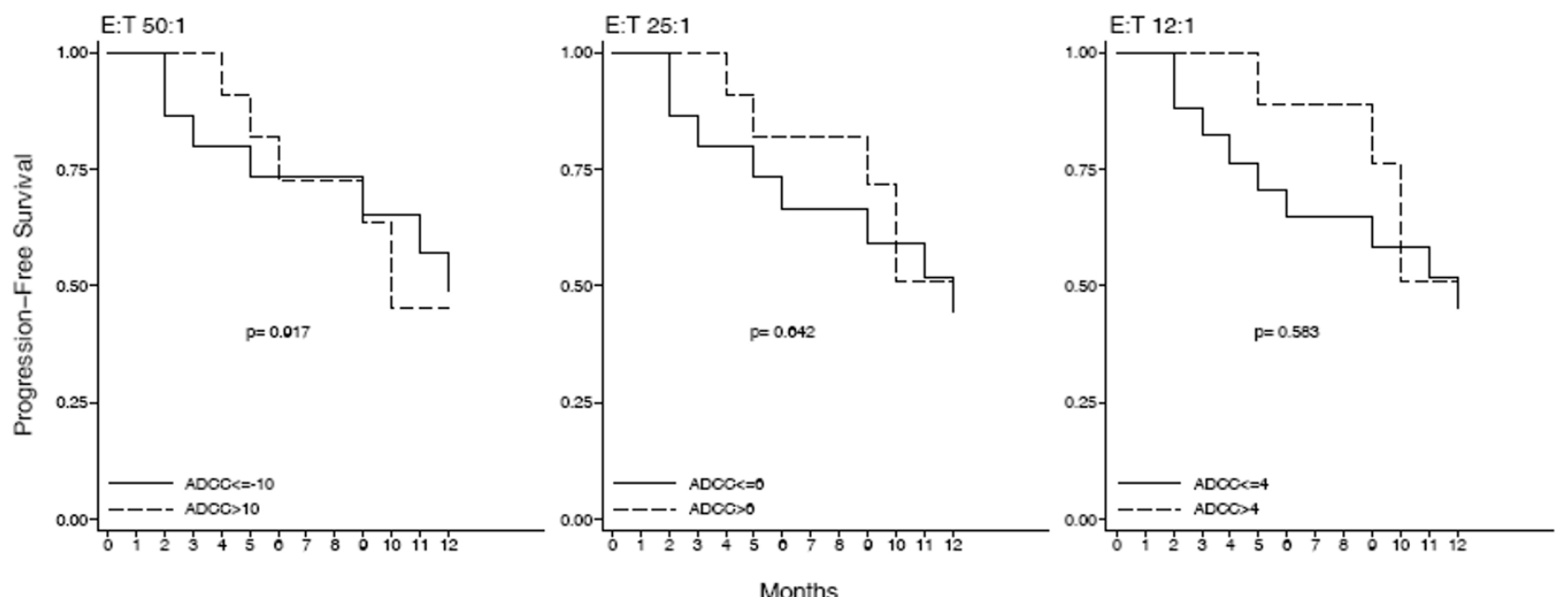

\section{Figure 7}

Time to tumor progression is not correlated with the ADCC activity. A cut-off of $10 \%, 6 \%$ and $4 \%$ cytotoxicity was arbitrarly chosen to discriminate between high and low levels ADCC at the three E:T ratios of 50:I, 25:I and I 2:I respectively and a stratified PFS curve was created from these values. The pattern of the two curves and the Log-Rank test $p$ values demonstrated that time to tumor progression was not correlated with the ADCC.

\section{Conclusion}

Our finding that only patients who respond to trastuzumab after a six month observation have normal levels of NK and ADCC activities point to an important contribution of the host NK competence to the clinical response. The observation that longer (12 months) protection against tumor expansion is only associated with classical NK activity suggests that NK-associated mechanisms other than ADCC. are involved in long-term trastuzumab activity. A better prediction of trastuzumab response in individual patients may derive from the understanding of these mechanisms.

\section{List of abbreviations}

NK: Natural Killer; ADCC: Antibody Dependent Cell Cytotoxicity; PFS: Progression-Free Survival.

\section{Competing interests}

The authors declare that they have no competing interests.

\section{Authors' contributions}

LM had the idea for, coordinated and analysed experimental data, and wrote the report.

$\mathrm{AB}$ contributed to protocol design, patients enrolment, follow up and clinical care

DM and LC contributed to protocol design

MM, MAP and contributed to follow up and clinical care.
ES performed the NK and ADCC tests

DB performed flowcytometric analysis

AE performed statistical analysis

\section{Acknowledgements}

This work was supported by MIUR, Piedmont Region (Oncology Project) and the CeRMS/COES project funded by the "Compagnia di San Paolo/Fondazione Internazionale per la Ricerca e la Medicina Sperimentale (FIRMS)" and Associazione Italiana per la Ricerca sul Cancro (AIRC). D.B. is a recipient of a Research Fellowship from MIUR and E.S. has been supported by Molinette Hospital and FIRMS.

\section{References}

I. Boyle P, Ferlay ]: Cancer incidence and mortality in Europe. Ann Oncol 2005, 16:48I-488.

2. Slamon DJ, Clark GM, Wong SG, Levin WJ, Ullrich A, McGuire WL: Human breast cancer: correlation of relapse and survival with amplification of the Her-2/neu oncogene. Science 1987, 235: $177-182$.

3. Owens MA, Horten BC, Da Silva MM: HER2 amplification ratios by fluorescence in situ hybridization and correlation with immunohistochemistry in a cohort of 6556 breast cancer tissues. Clin Breast Cancer 2004, 5:63-69.

4. Ross JS, Fletcher JA, Linette GP, Ross JS, Fletcher JA, Linette GP: The Her-2/neu gene and protein in breast cancer 2003: biomarker and target of therapy. Oncologist 2003, 8:307-325.

5. Gusterson BA, Gelber RD, Goldhirsch A, Price KN, Säve-Söderborgh J, Anbazhagan R, Styles J, Rudenstam CM, Golouh R, Reed R: Prognostic importance of c-erbB-2 expression in breast cancer. International (Ludwig) Breast Cancer Study Group J Clin Oncol 1992, 10:1049-1056.

6. Hynes NE, Stern DF: The biology of erbB-2/neu/HER-2 and its role in cancer. Biochim Biophys Acta 1994, I 1 98: | 65- | 84.

7. Carter P, Presta L, Ridgway JB, Henner D, Wong WL, Rowland AM, Kotts C, Carver ME, Shepard HM: Humanization of an antip I 85HER2 antibody for human cancer therapy. Proc Natl Acad Sci USA 1992, 89:4285-4289. 
8. Slamon DJ, Leyland-Jones B, Shak S: Use of chemotherapy plus a monoclonal antibody against HER2 for metastatic breast cancer that overexpresses HER2. N Engl J Med 200I, 344:783-792.

9. Vogel CL, Cobleigh MA, Gutheil JC, Harris LN, Fehrenbacher L, Slamon DJ, Murphy M, Novotny WF, Burchmore M, Shak S, Stewart SJ, Press M: Efficacy and safety of trastuzumab as a single agent in first-line treatment of HER2-overexpressing metastatic breast cancer. J Clin Oncol 2002, 20:719-726.

10. Nahta R, Yu D, Hung MC, Hortobagyi GN, Esteva FJ: Mechanisms of Disease: understanding resistance to HER2-targeted therapy in human breast cancer. Nat Clin Pract Oncol 2006, 3:269-280.

II. Molina MA, Codony-Servat J, Albanell J, Rojo F, Arribas J, Baselga J: Trastuzumab (herceptin), a humanized anti-Her2 receptor monoclonal antibody, inhibits basal and activated Her2 ectodomain cleavage in breast cancer cells. Cancer Res 200I, 6I:4744-4749.

12. Yakes FM, Chinratanalab W, Ritter CA, King W, Seelig S, Arteaga CL: Herceptin-induced inhibition of phosphatidylinositol-3 kinase and Akt is required for antibody-mediated effects on p27, cyclin DI, and antitumour action. Cancer Res 2002, 62:4|32-4|4|.

13. Le XF, Claret FX, Lammayot A, Tian L, Deshpande D, LaPushin R, Tari AM, Bast RC Jr: The role of cyclin-dependent kinase inhibitor p27Kip I in anti-HER2 antibody-induced GI cell cycle arrest and tumour growth inhibition. I Biol Chem 2003, 278:2344I-23450.

14. Jackson JG, St Clair P, Sliwkowski MX, Brattain MG: Blockade of epidermal growth factor- or heregulin-dependent ErbB2 activation with the anti-ErbB2 monoclonal antibody $2 C 4$ has divergent downstream signaling and growth effects. Cancer Res 2004, 64:260I-2609.

15. Mohsin SK, Weiss HL, Gutierrez MC, Chamness GC, Schiff R, Digiovanna MP, Wang CX, Hilsenbeck SG, Osborne CK, Allred DC, Elledge R, Chang JC: Neoadjuvant trastuzumab induces apoptosis in primary breast cancers. J Clin Oncol 2005, 23:2460-2468.

16. Tokuda $Y$, Ohnishi $Y$, Shimamura K, Iwasawa M, Yoshimura M, Ueyama $Y$, Tamaoki N, Tajima T, Mitomi T: In vitro and in vivo anti-tumour effects of a humanised monoclonal antibody against c-erbB-2 product. $\mathrm{Br} J$ Cancer 1996, 73:1362-1365.

17. Cooley S, Burns LJ, Repka T, Miller JS: Natural killer cell cytotoxicity of breast cancer targets is enhanced by two distinct mechanisms of antibody-dependent cellular cytotoxicity against LFA-3 and HER2/neu. Exp Hematol 1999, 27:I533-I54I.

18. Clynes RA, Towers TL, Presta LG, Ravetch JV: Inhibitory Fc receptors modulate in vivo cytoxicity against tumor targets. Nat Med 2000, 6:443-446.

19. Carson WE, Parihar R, Lindemann MJ, Personeni N, Dierksheide J, Meropol NJ, Baselga J, Caligiuri MA: Interleukin-2 enhances the natural killer cell response to Herceptin-coated Her2/neupositive breast cancer cells. Eur J Immunol 200I, 3 I:30I6-3025.

20. Repka T, Chiorean EG, Gay J, Herwig KE, Kohl VK, Yee D, Miller JS: Trastuzumab and interleukin-2 in Her2-positive metastatic breast cancer: a pilot study. Clin Canc Res 2003, 9(7):2440-2446.

21. Gennari R, Menard S, Fagnoni F, Ponchio L, Scelsi M, Tagliabue E, Castiglioni F, Villani L, Magalotti C, Gibelli N, Oliviero B, Ballardini B, Da Prada G, Zambelli A, Costa A: Pilot study of the mechanism of action of preoperative trastuzumab in patients with primary operable breast tumors overexpressing HER2. Clin Cancer Res 2004, 10:5650-5655.

22. Arnould L, Gelly M, Penault-Llorca F, Benoit L, Bonnetain F, Migeon C, Cabaret V, Fermeaux V, Bertheau P, Garnier J, Jeannin J-F, Coudert B: Trastuzumab-based treatment of HER2-positive breast cancer: an antibody-dependent cellular cytotoxicity mechanism? British Journal of Cancer 2006, 94:259-267.

23. Robertson MJ, Ritz J: Biology and clinical relevance of human natural killer cells. Blood 1990, 76:242I-2438.

24. Lozzio BB, Lozzio CB: Properties of the K562 cell line derived from a patient with chronic myeloid leukemia. Int J Cancer 1977, 19:136-139.

25. Matera L, Beltramo E, Martinuzzi E, Buttiglieri S: Effect of prolactin on carcinoembryonic antigen-specific cytotoxic $\mathbf{T}$ lymphocyte response induced by dendritic cells. Clin Exp Immunol 2004, 137:320-328.

26. Fleming GF, Meropol NJ, Rosner GL, Hollis DR, Carson WE 3rd, Caligiuri M, Mortimer J, Tkaczuk K, Parihar R, Schilsky RL, Ratain MJ: A phase I trial of escalating doses of trastuzumab combined with daily subcutaneous interleukin 2: report of cancer and leukemia group B 966 I. Clin Cancer Res 2002, 8:37I 8-3727.

27. Parihar R, Nadella $P$, Lewis $A$, Jensen $R$, De Hoff $C$, Dierksheide JE, VanBuskirk AM, Magro CM, Young DC, Shapiro Cl, Carson WE: A phase I study of interleukin I 2 with trastuzumab in patients with human epidermal growth factor receptor-2-overexpressing malignancies: analysis of sustained interferon gamma production in a subset of patients. Clin Cancer Res 2004, 10:5027-37.

28. Cartron G, Dacheux L, Salles G, Solal-Celigny P, Bardos P, Colombat $P$, Watier $\mathrm{H}$ : Therapeutic activity of humanized anti-CD20 monoclonal antibody and polymorphism in IgG Fc receptor FcgammaRIlla gene. Blood 2002, 99:754-758.

29. Varchetta S, Gibelli N, Oliviero B, Cardini E, Gennari R, Gatti G, Santos Silva L, Villani L, Tagliabue E, Ménard S, Costa A, Fagnoni FF: Elements Related to Heterogeneity of Antibody-Dependent Cell Cytotoxicity in Patients Under Trastuzumab Therapy for Primary Operable Breast Cancer Overexpressing Her2. Cancer Research 2007, 67:1|99|-I| 999.

30. Seliger B, Ritz U, Ferrone S: Molecular mechanisms of HLA class $I$ antigen abnormalities following viral infection and transformation. Int I Cancer 2006, I 1 8: 129-383I.

3I. Shahied LS, Tang Y, Alpaugh RK, Somer R, Greenspon D, Weiner LM: Bispecific minibodies targeting HER2/neu and CD 16 exhibit improved tumour lysis when placed in a divalent tumour antigen binding format. J Biol Chem 2004, 279:53907-539I4.

32. Roda JM, Parihar R, Magro C, Nuovo G], Tridandapani S, Carson WE 3rd: Natural Killer Cells Produce T Cell-Recruiting Chemokines in Response to Antibody-Coated Tumor Cells. Cancer Research 2006, 66:517-526.

33. Roda JM, Joshi T, Butchar JP, McAlees JW, Lehman A, Tridandapani S, Carson WE 3rd: The Activation of Natural Killer Cell Effector Functions by Cetuximab-Coated, Epidermal Growth Factor Receptor-Positive Tumor Cells is Enhanced By Cytokines. Clinical Cancer Research 2007, 1 3:641 9-6428.

Publish with BioMed Central and every scientist can read your work free of charge

"BioMed Central will be the most significant development for disseminating the results of biomedical research in our lifetime. "

Sir Paul Nurse, Cancer Research UK

Your research papers will be:

- available free of charge to the entire biomedical community

- peer reviewed and published immediately upon acceptance

- cited in PubMed and archived on PubMed Central

- yours - you keep the copyright
BiolMedcentral 